\title{
The role of natural products in modern drug discovery.
}

\author{
JOÃO B. CALIXTO \\ Centro de Inovação e Ensaios Pré-clínicos/CIEnP, Avenida Luiz Boiteux Piazza, \\ 1302, Cachoeira do Bom Jesus, 88056-000 Florianópolis, SC, Brazil \\ Manuscript received on January 30, 2019; accepted for publication on April 15, 2019
}

\begin{abstract}
How to cite: CALIXTO JB. 2019. The role of natural products in modern drug discovery. An Acad Bras Cienc 91: e20190105. DOI 10.1590/0001-3765201920190105.

Abstract: The global medicine market is about 1.1 trillion US dollars. About 35 percent of medicines have originated from natural products. Brazil presents the largest biodiversity in the world, with more than 50,000 species of higher plants. However, few innovative products have been developed in Brazil from active constituents derived from the Brazilian biodiversity. Scientific evidences on plants and venoms have been internationally published by Brazilian scientists over the last 4 decades; but few examples of innovative products are commercially available. Few examples include the anti-hypertensive drug captopril first identified in the venom of the Brazilian viper Bothrops jararaca by Professor Sergio Ferreira; and some phytotherapeutic agents such as Acheflan ${ }^{\circledR}$, Syntocalmy ${ }^{\circledR}$ and Melagrião ${ }^{\circledR}$ produced by standardized plant extracts with scientific proof of safety, efficacy and quality. Still, only Acheflan ${ }^{\circ}$ and Melagrião ${ }^{\circledR}$ are obtained from native Brazilian plants. Several issues contribute to the lack of innovative products from the Brazilian biodiversity, but in my opinion, the most challenging ones are i) the lack of specific regulations to allow researchers and companies to access biodiversity for the purposes of scientific and technological innovation; and ii) the absence of a long-term government program to support research and innovation in this field.
\end{abstract}

Key words: Brazilian biodiversity, new drug development, drug discovery, cosmetic.

\section{INTRODUCTION}

Since ancient times, natural products mainly plants, minerals, animals etc. have been widely used to treat many diseases. There are registers showing medicinal uses of such substances by people from thousands of years before Christ. Medicinal plants and microorganisms were the major source of medicines over many centuries.

E-mail: joao.calixto@cienp.org.br ORCid: https://orcid.org/0000-0003-4041-7153

This paper is dedicated to the memory of two outstanding Brazilian pharmacologists, Professor Mauricio Rocha e Silva (1910 - 1982) and Professor Sérgio Henrique Ferreira (1934-2016)
We have many examples of plant-derived extracts and/or compounds isolated from plants that have been widely used in the treatment of many significant diseases. To name just two examples, poppy (Papaver somnniferum) and marijuana (Cannabis sativa) have been used for as long as 4,000 years. In 1806 Friedrich Serturner isolated the alkaloid morphine from poppy: an event that prompted a continuing search for other plantderived medicines. In 1824 Pierre-Jean Robiquet isolated the anti-tussive agent codeine, also from poppy, and in 1848 George Merck Fraz isolated the anti-spasmodic alkaloid papaverine from the 
same plant. Amongst the many other important active principles isolated from medicinal plants are atropine (muscarinic antagonist), isolated from Atropa belladonna by Mein in 1831; caffeine, obtained by Runge in 1820 from Coffea arabica; digoxin (digitalis), isolated by Claude-Adolphe Nativelle in 1869 from Digitalis lanata and curare (muscle relaxant), isolated by Winstersteiner and Dutcher in 1943 from the South American plant Chondrodendron tomentosum.

\section{THE CONTRIBUTION OF BIOLOGICALLY DERIVED PRODUCTS TO THE DEVELOPMENT OF NEW MEDICINES}

The annual global medicine market is worth about 1.1 trillion US dollars. About 35 percent of these medicines originated directly or indirectly from natural products including: plants $(25 \%)$, microorganisms (13\%) and animals (about 3\%): natural-derived products constitute an extremely important resource for global pharmaceutical companies working on the development of new medicines. They are used as: i) a direct source of therapeutic agents, (both as pure drugs and phytomedicines); ii) a source of raw material for development of complex, semi-synthetic drugs; iii) prototypes for design of lead molecules; iv) as taxonomic markers for discovery of new drugs). About one third of the best-selling drugs in the word are natural products or their derivatives. Of the 520 new drugs approved by Food and Drug Administration (FDA) between 1983 and 1994, $39 \%$ were natural products or derived from natural products and about $60-80 \%$ of antibiotics and anti-cancer drugs are derived from natural products (Cragg et al. 1997, Strohl 2000, Harvey 2000). Recently Newman and Cragg (2016) assessed the role of natural products in the drugs approved by the FDA between 1981 and 2014. They found that in this period the FDA approved 1,562 drugs, 64 (4\%) were unaltered natural products, $141(9.1 \%)$ were botanical drugs (mixture), 320 (21\%) were natural product derivatives and $61(4 \%)$ were synthetic drugs but with natural products pharmacophore.

There are many examples of globally best-selling medicines that originated from natural products - notably from higher plants, microorganism and animals. Some good examples are: i) the anti-cholesterolaemic agents simvastain, lovastatin, pravastatin and atorvastatin; ii) the anti-hypertensive agents: captopril and enalapril; iii) the immnosuppressive agents cyclosporin A, tacrolimus (FK506) and rampamycin; iv) the antitumoral agents taxol, docetaxel and campothecin; v) the antibiotic and antifungal agents: penicillin, erythromicin, clarithomycin and anphotericin B. (Strohl 2000, Harvey 2000, Li and Vederas 2009).

As noted above animals are the source of about $3 \%$ of the new drugs approved by the FDA, but many important and best-selling drugs originated from animals, mainly from toxins. Captopril, an angiotensin-converting enzyme (ACE) inhibitor and anti-hypertensive drug was discovered by Brazilian pharmacologist Sergio H. Ferreira (1934 - 2016) in the venom of the Brazilian viper, Bothrops jararaca. This is discussed in more detail in the next section. Enalapril was later developed using the same mechanism. Other examples of animal-derived drugs are exanatide, a glucagonlike peptide 1 agonist used to treat type 2 diabetes mellitus, which was originally isolated from the gila of the monster lizard (Heloderma suspsctan) and ziconotide, a peptide isolated from Conus magus which is a calcium 2.2 channel blocker used to treat neuropathic pain (for more detail about new drugs derived from animal toxins see: http://zoltantakacs. com/zt/sc/venoms_medical.shtml).

There are some clear advantages to the use of natural products in the process of drug discovery and development. They represent chemical novelties and compared with other sources they can originate lead drug candidate for complex targets. Furthermore, naturally derived constituents 
possess a chemical diversity unmatched by any synthetic chemical collection; they can possess bi- and tri-dimensional complex structures yet be capable of being absorbed and metabolised in the body (Strohl 2000). On the other hand, the use of naturally derived molecules as source of new medicines also presents some challenges because of the lack of specific legislation governing access to biological resources in biodiversity-rich countries. It may also be physically difficult to gain access to natural habitats and the processes necessary to isolate, purify and chemically characterise active compounds are costly and time-consuming. Most pharmaceutical companies complain about the difficulty of assaying some natural molecules in modern drug discovery programmes (high throughput screening) compared with synthetic compounds. Finally, is important to emphasise the great structural complexity of natural molecules, which makes it difficult to synthesise analogous lead compounds (Strohl 2000, Harvey 2000, $\mathrm{Li}$ and Vederas 2009). Without doubt the global pharmaceutical industry has benefited greatly from biodiversity-rich countries over the last two centuries when it comes to identification of novel therapeutic targets involved in many significant chronic diseases and, particularly, the development of new drugs for the management of certain chronic diseases (see for review Newman and Cragg, 2016).

Brazil is the most biodiverse country in the world, with more than 50,000 species of higher plants (20 $-22 \%$ of the planetary total), more than 500 species of mammals, about 3,000 species of fish, more than 1,500 species of birds, more than 500 species of amphibians and millions of species of insects and microorganisms (http://www.sibbr. gov.br/areas/?area=biodiversidade). However, to date few innovative products have been developed and marketed in Brazil or abroad from active constituents derived from Brazilian biodiversity. Despite the growing number of scientific articles published internationally by Brazilian scientists on plants over the last 4 decades (for review see Calixto 2005, Dutra et al. 2016), we have seen that there is a negative correlation between the number of scientific papers published on Brazilian biodiversity and the number of innovative products derived from the Brazilian biome that are available on the market. I return to this topic later on in this article.

\section{FROM THE DISCOVERY OF BRADYKININ TO THE DEVELOPMENT OF CAPTOPRIL}

In 1949, Rocha e Silva (1910 - 1983) and Wilson Teixeira Beraldo (1917 - 1998), who were working at the São Paulo State Biological Institute, discovered the peptide bradykinin (BK), a hypotensive agent that stimulate smooth muscles and is released in plasma by the action of venom of the Brazilian viper, Bothrops jararaca or by trypsin. This discovery was first published in the first number of the journal Ciencia e Cultura, from the newly created Brazilian Society for the Advance of Science, which numbered Rocha amongst its founders (Rocha e Silva and Beraldo 1949). In the same year this discovery was published in the American Journal of Physiology (Rocha e Silva et al. 1949) and the article became a much-cited classic.

At the beginning of 1960s Sergio Henrique Ferreira (1934 - 2016), then a young physician who had graduated from the University of São Paulo, moved to Ribeirão Preto to begin a $\mathrm{PhD}$ in Pharmacology under supervision of Professor Mauricio Rocha e Silva (Fig. 1). Professor Rocha e Silva suggested that Sergio continue work with the venom of the Brazilian viper, Bothrops jararaca. Sergio subsequently discovered that the venom of Bothropsjararaca had a veryinteresting potentiating effect on the contractile action of bradykinin in the guinea pig ileum and on bradykinin-induced hypotension and he and colleagues identified the active substance responsible as bradykinin- 


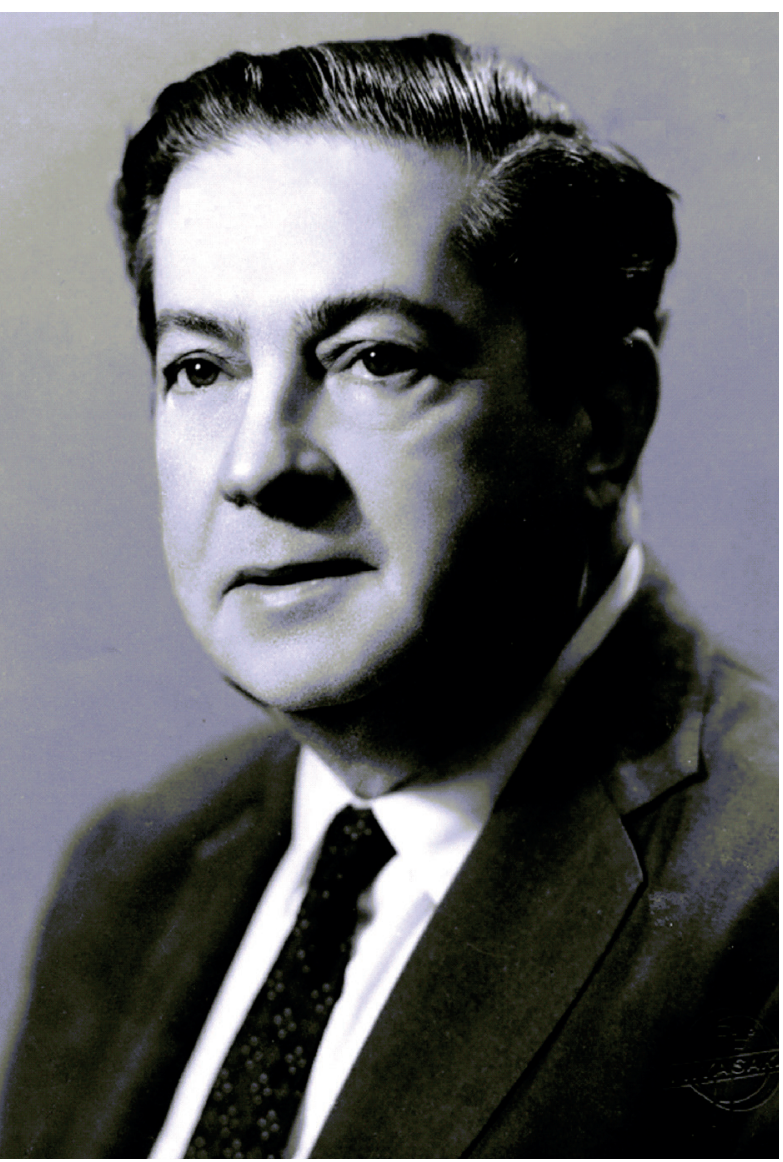

Figure 1 - Professor Maurício Rocha e Silva.

potentiating factor (BPF). These results were published in the British Journal of Pharmacology in 1965 (Ferreira 1965). Further investigation of BPF was carried out in collaboration with many researchers from the Faculty of Medicine of Ribeiro Preto allowed to isolate and to sequence two active peptides, the pentapeptide BPP5 and the nonapeptide BPP9 (Bakhle and Flower 2017).

As soon as he finished his doctorate Sergio decided to spend some years as a post-doctoral researcher in London, at the Professor John Vane Laboratory in the Institute of Basic Medical Science at the Royal College of Surgeons of England. Sergio took with him to London a small sample of the purified BPF for which he and his collaborators had already determined the amino acid sequence and suggested that this venomderived peptide inhibited the enzyme that degrades
BK, which was later recognised to be the enzyme that transforms inactive peptide angiotensin I into the potent hypertensive agent angiotensin II in the body. At the time Professor John Vane was studying some of the mechanisms involved in the control of hypertension and asked to assess whether BPF could interfere with ACE. BPF was found to be a strong ACE inhibitor and these new and interesting results encouraged John Vane to assess BPF as a new tool for development of a new drug to treat hypertension. At the time he was a consultant to the Squibb Pharmaceutical Company in New Jersey, USA. Vane suggested that Squibb should continue the pre-clinical and clinical studies of BPF to develop a new therapy to treat high blood pressure. After overcoming many challenges, in particular the need to convert the BPF peptide into a stable peptide for oral administration and develop largescale method of synthesising this peptide, as well as the need for clinical research, captopril was finally approved by the FDA in the early 1980s (trade name capoten), allowing the company's first drug to sell one billion dollars. Currently there are about nine ACE inhibitors on the market and together their sales are worth more than 5 billion dollars per annum (Smith and Vane 2003). In 1982 John Vane was awarded the Nobel Prize for Medicine and Physiology for his contributions to research on the mechanism of action of aspirin and other non-steroidal anti-inflammatory drugs and for the discovery of prostaglandins. Sergio spent many years working at the Vane's laboratory and coauthored many papers on these fields (Fig. 2).

It is quite clear, therefore, that without the effort of Professor John Vane and his connection with Squibb Pharmaceutical Company BPF, first identified in the venom of the Brazilian viper Bothrops jararaca by Professor Sergio Ferreira and collaborators, would not have gained FDA approval as an innovative drug and would not have gone on to be used worldwide to treat arterial hypertension. 


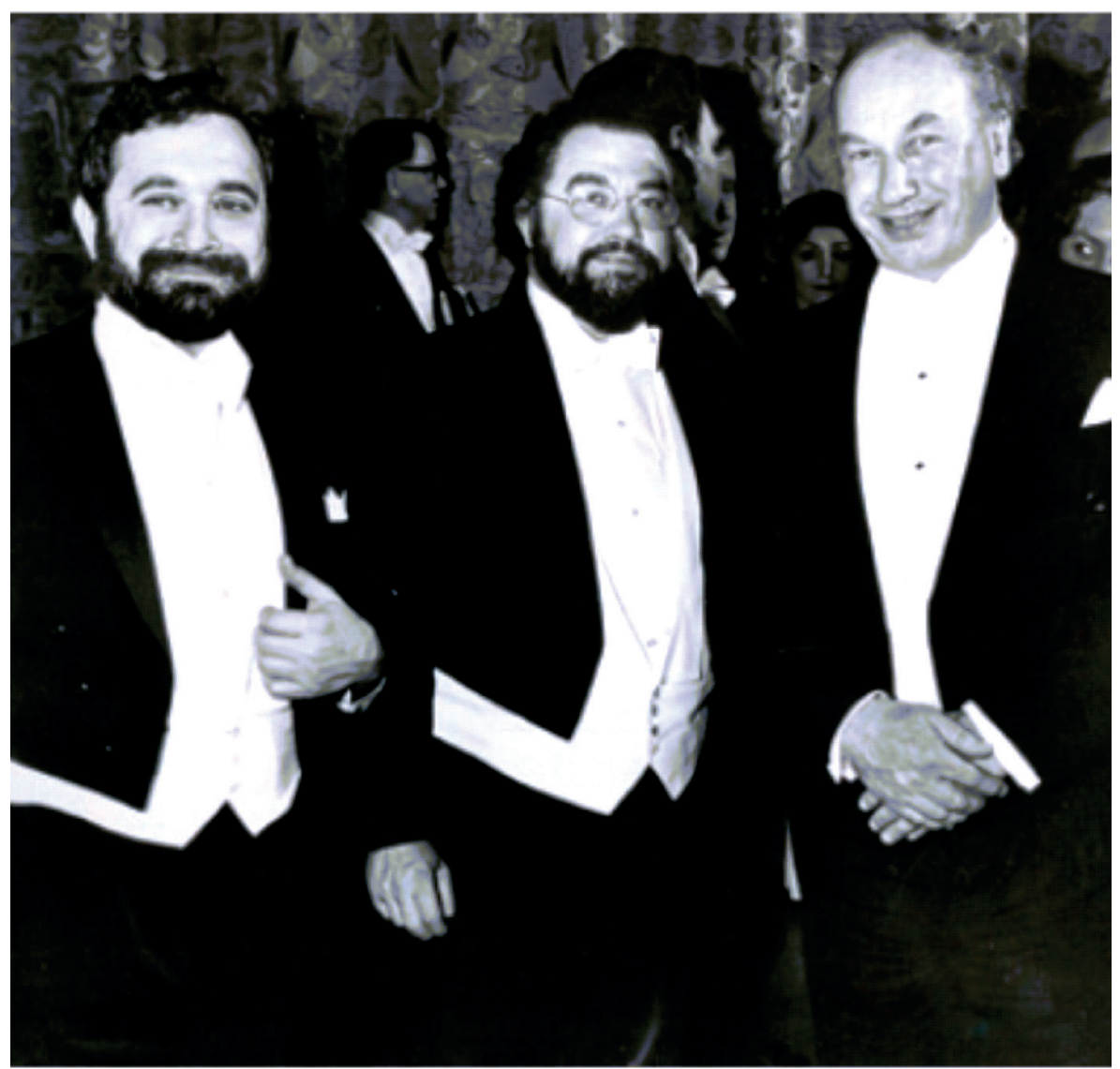

Figure 2 - From the right to the left: John R. Vane, Sergio H. Ferreira and Salvador Moncada in the ceremony of Nobel Prize granted to John Vane, 1982.

\section{THE EFFORTS OF OUR GROUP TO COLLABORATE WITH BRAZILIAN PHARMACEUTICAL COMPANIES TO DEVELOP NEW PHYTOTHERAPEUTIC AGENTS FROM BRAZILIAN FLORA}

Phytotherapeutic agents are standardised extracts obtained from one or more plants that have been shown to be safe and effective in scientific clinical studies, meet quality standards and have been approved for human use in Brazil and many other countries (for review see Calixto 2000). Since the early 1990s we have established a close partnership with Brazilian pharmaceutical companies in order to develop some innovative biologically derived products. We have carried out more than one hundred projects supported by these industries, resulting in about 12 internationally approved patents, many publications and 3 products that have met scientific standards for safety, efficacy and quality and received approval from Agência Nacional de Vigilância Sanitária (ANVISA), a Brazilian agency with a similar remit to the FDA. These products are the analgesic and anti-inflammatory Acheflan ${ }^{\circledR}$, obtained from the essential oil of Codia verbenacea, Syntocalmy ${ }^{\circledR}$, which is produced from the leaves of Passiflona incarnata (a European plant) and used in the treatment of anxiety and insomnia (both marketed by Aché Laboratorios) and Melagrião ${ }$, developed from the leaves of Mikania glomerata and used for the management of cough and asthma, marketed in Brazil by Catarinense Pharma. According to the IMS health Brazilian sales of Acheflan ${ }^{\circledR}$, Syntocalmi ${ }^{\circledR}$ and Melagrião ${ }^{\circledR}$ in 2016 were worth $30.3,28.6$ and 23.6 million of reals, 
respectively. Of the top 20 phytotherapeutic agents marketed in Brazil between 2014 and 2016 only the 3 above-mentioned phytomedicines make part of the list. So far, only two phytotherapeutic agents from Brazilian flora were approved for human use and are currently on the market (Cordia verbenacea and Mikania glomerata). In addition to the above-mentioned products studied by our group at the Department of Pharmacology of the Federal University of Santa Catarina), 3 more new phytomedicines are now under clinical development and two others failed to demonstrate efficacy in the late phase of clinical studies.

\section{THE RELEVANCE OF BRAZILIAN BIODIVERSITY TO THE DEVELOPMENT OF NEW COSMETICS}

Few Brazilian scientists are currently interested in studying the Brazilian biome in order to develop innovative cosmetic products. However, the Brazilian cosmetic market has been growing at a high rate over the last decade, reaching annual sales of about 13 billion US dollars in 2016. There are 2,642 ANVISA-registered companies that sell cosmetics in Brazil. These companies are represented in almost all Brazilian states, except for the state of Roraima.

Amongst the many examples of plants native to Brazil that have been the source of innovative cosmetic products are babacú (Orbignya speciosa), murumuru (Astrocaryum murumuru), bacuri (Platonia insignis), buriti (Mauritia flexuosa), acaí (Euterpe oleracea), umbu and umbu-cajá (Spondias tuberosa). In 2008, through a partnership between Federal University of Santa Catarina, Financiadora de Estudos e Projetos (FINEP) and Natura cosmetic company, our group studied the standardised extract of the leaves of Passiflora alata, a native plant of Brazil. This project allowed Natura company to develop an innovative cosmetic product, named flavonoid of passiflora, that is still commercially available. The data discussed above suggest that scientific research on the Brazilian biome in partnership with the cosmetics industry should be encouraged, with the aim of developing innovative products (https://abihpec.org.br/ publicacao/panorama-do-setor-2018).

\section{CONCLUSIONS}

Given the discussion in this brief article, the question that needs to be answered is why does Brazil not yet have a long-term programme to support high quality scientific and technological research into using its rich biome as a source of medical innovations? I think there are several issues involved, but I will focus on some of the challenges we have yet to overcome. The most significant is the lack of a specific law that allows researchers and companies access to genetic knowledge for the purposes of scientific and for technological innovation. This issue has been widely debated by the Brazilian national congress and by researchers and industries since 2000, when the President of the republic of Brazil proposed a bill that would regulate access to the Brazilian biome for the purposes of research and technological innovation. After much discussion this law was finally approved by the congress in 2015 (law number 13123/2015). However, although some progress has been made, the handling of several issues remain unclear: i) genetic knowledge: information on genetic origin of substances originating from the metabolism of these living beings; ii) associated traditional knowledge: knowledge that indicates a potential use for genetic knowledge; iii) prior, informed consent: permission given by the holder for the associated traditional knowledge for its use in research and innovation and iv) access: permission to collect material for scientific research and technological development. Brazil will have to deal with the major challenges these issues present if it wants to study its rich biome scientifically and use it to develop innovative products with benefits for human health 
and well-being. We have wasted almost two decades discussing the issues surrounding access to and use of the Brazilian biome and the main problems have still not been resolved. During this period Brazilian scientists and industries were unable to study and develop innovative projects derived from the Brazilian biome, many species became extinct and all the while foreign researchers continue to study our biome.

\section{REFERENCES}

BAKHLE YS AND FLOWER RJ. 2017. Sergio Henrique Ferreira (1934-2016). Br J Pharmacol 174: 341-342.

CALIXTO JB. 2000. Efficacy, safety, quality control, marketing and regulatory guidelines for herbal medicines (phytotherapeutic agents). Braz J Med Biol Res 33: 179189.

CALIXTO JB. 2005. Twenty-five years of research on medicinal plants in Latin America: a personal view. J Ethnopharmacol. 22:131-134.

CRAGG MG, NEWMAN DJ AND SNADER KM. 1997. Natural products in drug discovery and development. J Nat Pro 60: 52-60.
DUTRA RC, CAMPOS MM, SANTOS AR AND CALIXTO JB. 2016. Medicinal plants in Brazil: Pharmacological studies, drug discovery, challenges and perspectives. Pharmacol Res 112: 4-29.

FERREIRA SH. 1965. A bradykinin-potentiating factor (BPF) present in the venom of Bothrops jararaca. Br J Pharmacol 24: 163-169.

HARVEY A. 2000. Strategies for discovering drugs from previously unexplored natural products. Drug Disc Today 5: 294-299.

LI JW-H AND VEDERAS J. 2009. Drug discovery and natural products: End of an era or an endless frontier? Science 325:161-165.

NEWMAN DJ AND CRAGG GM. 2016. Natural products as sources of new drugs from 1981 to 2014. J Nat Prod 79(3): 629-661.

ROCHA E SILVA M AND BERALDO WT. 1949. Um novo princípio ativo auto- farmacológico (bradicinina) liberado do plasma sob a ação do veneno de cobra e da tripsina. Ciência e Cultura 1-2: 32-35.

ROCHA E SILVA M, BERALDO WT AND ROSENFELD G. 1949. Bradykinin a hypotensive and smooth muscle stimulating factor released from plasma globulin by snake venoms and trypsin. Am J Physiol 156: 261-276.

SMITH CG AND VANE JR. 2003. The discovery of captopril. FASEB 17: 788-789.

STROHL WR. 2000. The role of natural products in a modern drug discovery program. Drug Disc Today 5: 39-41. 